http://nv.nltu.edu.ua

https://doi.org/10.15421/40270635

$@ \bowtie$ Correspondence author

Article received 23.09.2017 p.

O. M. Romaniuk

Article accepted 28.09.2017 p.

o.m.romaniuk@gmail.com

УДК 532.137

O. M. Romaniuk, B. A. Kril, O. V. Kril, H. B. Krykh

Lviv Polytechnic National University, Lviv, Ukraine

\title{
ROTATIONAL PAPER PULP VISCOMETER WITH MEASUREMENT AT TWO SHEAR SPEEDS
}

Maintaining of the proper predetermined paper pulp consistency on the different stages of the paper or cardboard manufacturing process significantly affects on quality and self cost of manufactured articles. The improvement of precision and repeatability of the paper pulp viscosity and consistency measurements is relevant to paper industry. Objective of the work is to improve the industrialtype paper pulp rotational consistometer. A new method for measurement of paper pulp concentration by means of a rotational viscometer was suggested which enables determining the flow consistency index $K$ and flow behavior index $n$ in the Ostwald-de Waele power law. The influence of the following torques on the measurement results is eliminated thanks to the new method: the friction torque in the seal of the sensitive element, the friction torque in the bearings of the shaft and the torque created under the influence of the flow with distorted flow speed profile. This is achieved by measuring the torque which acts on the sensitive element approaching the selected frequencies of sensitive element rotation both from the lower and higher frequencies. The mean torque value is calculated based on the obtained values. The measurements are conducted for two sensitive element rotation frequencies adjusted in advance. The frequency of sensitive element rotation is changed by means of a frequency converter. It is shown that by using two different rotation frequencies of the sensitive element of a rotational viscometer it is possible to define the flow consistency index and the flow behavior index. Paper pulp viscosity and consistency is defined on the basis of these two indexes. It is also suggested to average the results of viscous friction torque measurement approaching the rotation frequency of the viscometer sensitive element to the working frequency chosen for measurement from the lower and higher frequency ranges. By averaging the results of such measurement the friction torques in sealing and bearings supporting the sensitive element shaft are compensated. By changing the rotation direction of the sensitive element and by further averaging the obtained results it is possible to eliminate the influence of the asymmetrical distribution of paper pulp flow speed in the pipeline. This improves accuracy of the paper pulp consistency measurement.

Keywords: paper pulp consistency measurement; rotational viscometer; non-Newtonian fluids; consistency ratio; flow behavior index; effective viscosity.

\section{Definition of the scientific problem studied in the research}

Maintaining the proper predetermined paper pulp consistency on various stages of its preparation in paper or cardboard manufacturing process can significantly influence the quality and cost of production. Permanent monitoring of paper pulp consistency is most commonly performed indirectly by measuring paper pulp viscosity, as presence of uncontrolled contaminating foreign materiel in the recycled paper makes it problematic to reliably determine paper pulp consistency by means of measurement of absorption, scattering, or polarization of the optical (Waller, 1993) or super high frequency electromagnetic waves (Jakkula \& Tahkola, 2000). Therefore, improvement of the rotational type viscometer method for paper pulp concentration measurement is proposed in this paper.

\section{Analysis of the recent publications and researches on the topic}

Paper pulp is a non-Newtonian fluid, in which the relation between the shear stress $\sigma$ and the shear rate $\dot{\gamma}$ is nonlinear. It is described by the Ostwald-de Waele power law (Steffe, 1996):

$$
\sigma=K(\dot{\gamma})^{n}
$$

where $K$ is the consistency index; $n$ is flow behavior index, its value for pseudoplastic fluids is in the range of $0,7<n<1$.

To describe the viscosity of the abovementioned fluids the effective viscosity is used as well (Steffe, 1996):

$$
\mu=f(\dot{\gamma})=\frac{\sigma}{\dot{\gamma}}=K(\dot{\gamma})^{n-1} \text {. }
$$

Obviously, determining exact set of two unknown

Інформація про авторів:

Романюк Олександр Миколайович, аспірант кафедри автоматизації та комп'ютерно-інтегрованих технологій.

Email: o.m.romaniuk@gmail.com

Кріль Богдан Андрійович, канд. техн. наук, ст. наук. співробітник, доцент кафедри автоматизації та комп'ютерно-інтегрованих технологій. Email: kril@robitnia.com

Кріль Олександр Васильович, ст. викладач кафедри автоматизації та комп'ютерно-інтегрованих технологій.

Email: kril@robitnia.com

Крих Ганна Бориславівна, канд. техн. наук, доцент кафедри автоматизації та комп'ютерно-інтегрованих технологій Email: gannakrih@gmail.com

Цитування за ДСТУ: Romaniuk О. М., Kril В. A., Kril O. V., Krykh H. B. Rotational paper pulp viscometer with measurement at two shear speeds. Науковий вісник НЛТУ України. 2017. Вип. 27(6). С. 172-177.

Citation APA: Romaniuk, O. M., Kril, B. A., Kril, O. V., \& Krykh, H. B. (2017). Rotational Paper Pulp Viscometer with Measurement at Two Shear Speeds. Scientific Bulletin of UNFU, 27(6), 172-177. https://doi.org/10.15421/40270635

172 Науковий вісник НЛТУ України, 2017, т. 27, № 6 Scientific Bulletin of UNFU, 2017, vol. 27, no 6 
values $K$ and is not possible with measurements performed in one mode only. Therefore at least two different measurement modes need to be used to obtain both values.

Based on the literature review (Blanco et al., 2007) it was defined that the most accurate industrial viscosity measurements are accomplished with application of rotational viscometer with sensitive elements in form of two parallel disks, one of which is a rotating propeller. The propeller induces the rotational flow of the fluid and the other disc (impeller) is used to measure the friction torque in the examined fluid. This design is not suitable for paper pulp since in order to measure friction torque the distance between the discs shall be small ( 1 to $2 \mathrm{~mm}$ ) and this space will be clogged by paper pulp fibers. That is why a disklike sensitive element or a rotor with blades of different shapes is used. The paper pulp is caught by the sensitive element and a layer with viscous friction on the surface of such a flat or a spatial core is created. The streamline form and absence of small gaps make such sensitive element designs applicable for measurements in fibrous fluids.

Let's look into the sensitive element of a paper pulp consistometer shaped as a disk with a radius $R$, on the surface of which the viscous friction layer emerges with an average thickness of $h$ (Fig. 1). Similar to development of the formula of viscous torque calculation for two disk sensor in viscous media (Steffe, 1996), with some assumptions and corrections at experimental determination of the $h$ value, the formula for calculation of friction torque $M$ acting on the flat disk sensor that is rotating in the viscous non-Newtonian fluid, behavior of which is described by the power law, can be described in the following form:

$$
\frac{M(3+n)}{4 \pi R^{3}}=K\left(\frac{\Omega R}{h}\right)^{n}=K\left(\dot{\gamma}_{R}\right)^{n} .
$$

Where $\Omega=2 \pi f-$ angular velocity of disk rotation, $f-$ disk rotation frequency; $n$ - flow behavior index; $K-$ consistency index and $\dot{\gamma}_{R}$ - shear rate at the edge of the disk (at the distance $R$ from the geometrical axis of rotation).

When the rotation viscometer is in operation the viscous friction torque $M$ emerging between the moving and still layers of the fluid is determined based on (3). At the same time the moving layer is captured and is moving simultaneously with the disk sensitive element being rotated in the viscous fluid with the known frequency $f$. To eliminate the influence of the layering of the paper pulp on the surface of the sensitive element, radial fins are placed on the element. Thickness of the sensitive element with fins together with the thickness of two paper pulp layers with viscous friction is significant (up to 10 to $15 \mathrm{~mm}$ ). The viscous friction at the rim of such a sensitive element is not taken into account in formula (3) in order to simplify further explanations.

Besides the viscous friction torque the sensitive element shaft is also affected by the friction torque in the bearings $M_{\Pi}$ and by the friction torque $M_{S}$ in the shaft sealing which protects the viscometer measuring unit from leaking of the fluid. These torques are added to the viscous friction torque $M$ and distort its value. Thus there is a task of reducing or eliminating the influence of the abovementioned torques on the fluid viscosity measurement results. Let us take a closer look at this problem.
Usually there is no shaft sealing in the laboratory devices since the whole sensitive element is immersed into the fluid under study. The shaft of the sensitive element comes out of the fluid. The fluid is held in an open viscometer container under atmospheric pressure. The force of gravity keeps the fluid from getting into the measurement unit (US patent, 1973). Thus elimination of friction torque $M_{S}$ in the sensitive element shaft is not an issue for this type of design.

Such a type of viscometer cannot be applied for operation directly in the paper making pipeline where paper pulp is under significant overpressure. In this case sensitive element shaft should have a sealing that will protect the viscometer measuring unit from paper pulp (Oy \& Nygård, 2010). Such solution creates additional friction torque $M_{S}$ acting on the sensitive element shaft from the sealed side and it is added to the measured viscous friction torque from the fluid side. Thus, sealing the shaft of the sensitive element results in change of the torque value that is passed from the sensitive element to the measuring device and distorts the measurement results.

To reduce this error the impact of the friction torque in the sealing $M_{S}$ on the measurement results should be eliminated. There is a number of ways to achieve this:

1) To apply a sensitive element large enough to have viscous friction torque $M$ significantly higher than the friction torque in the sealing $M_{S}$. Then its influence could be neglected. Application of such method is restricted by the real dimensions of paper pulp pipelines that the device has to fit.

2) To measure the experimental dependence of $M_{S}$ on the sensitive element rotation speed and to make an appropriate correction in the calculated value of paper pulp viscosity. This method also requires data on the $M_{S}$ value changes depending on the duration and modes of operation of sealing.

3) To apply sealing that will function as an elastic element and the torsion angle of which is used to measure the viscous friction torque $M$ acting on the sensitive element. The problem is that the elastic properties of the small sealing torsions in the longitudinal corrugated thin-walled tube and their polymeric sealants are changing in the process of operation so the transduction function of the device will also be changing.

4) To apply an automatic tracking system that will rotate and auxiliary pipe shaft with the sensitive element axe inside of it, passing through the elastic sealing, and rotating with the same rotating speed. Sealing of the sensitive element shaft in this case is always untightened and the power of consumption of servomotor is proportional to the viscous friction torque $M$ (US patent, 2012).

5) To apply a measurement block design where the sealing provides a hermetic motionless junction of a sensitive element with the engine system through an elastic thinwalled tube, twist angle of which is providing information on the viscous friction torque impacting the sensitive element (US patent, 1997). Such design is hermetic and has no sealing, however working with paper pulp the space between the measuring tube and external tube that is the sensitive element case should be protected from paper pulp with a ring sealing in order to avoid deposition of solid particles and salts.

Thus in all the listed ways being applied for paper pulp viscosity measurement in the pipeline the sealing of the 
sensitive element shaft by means of an elastic polymer ring is applied as well as the torsion sealing based on a thin longitudinal corrugated tube and bearings for supporting the sensitive element shaft are applied. As a result, minimizing or eliminating the impact of friction torque of the abovementioned elements on the paper pulp viscosity measurement result has important impact on the accuracy of measurements with rotation viscometers.

\section{Purpose of the article}

The purpose of this article is to improve the ways of paper pulp consistency measurement by means of rotational viscometers. The improvement consists in measurement of shear force torque that emerges under the influence of viscous friction of paper pulp layer at two alternate rotation frequencies of the disk sensitive element.

\section{The suggested viscometer model and algorithm of processing the viscosity measurement results}

A device for paper pulp consistency measurement was studied that employs rotation method with a rotating disk element that is symmetrical related to the rotation direction (Fig. 1). The main hollow shaft is rotated with a preset frequency by means of a motor using energy from a frequency converter and it is causing the rotation of the paper pulp. There is another shaft placed into the first one with the disk sensitive element on it. During paper pulp rotation a viscous friction torque acts on the sensitive element. And the elastic torsion element is twisted by the sensitive element at angle $\varphi$. The angle value provides information on the viscosity and the associated paper pulp consistency.

\subsection{Suggested measuring device design}

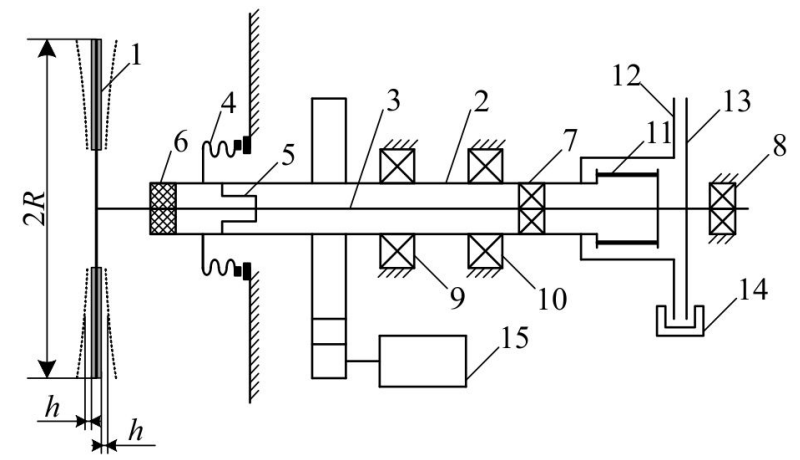

Fig.1. Design of the mechanical part of a rotational paper pulp concentration meter based on the viscosity measurement. 1) disk sensitive element; 2) main hollow shaft; 3) sensitive element shaft; 4) sealing of the main hollow shaft, consists of a bellow valve and a ring insertion made of tungsten carbide - cobalt alloy; 5) flexible sealing of a longitudinal corrugated thin-walled tube; 6 ) elastic sealing to protect the system $5 ; 7,8$ ) bearings of the sensitive element shaft; 9, 10) bearings of the main hollow shaft; 11) torsion spring of cylindrical rods; 12) disk with cutouts in the main hollow shaft; 13) disk with cutouts on the sensitive element shaft;

14) optical transducer of the disks 12 and 13 displacement angle; 15) motor powered by a frequency converter.

\subsection{Mathematical model of the device}

The viscous friction torque which acts on the disk being rotated in a viscous non-Newtonian fluid described by the power law is defined by the equation (3) for a disk sensitive element (possibly with symmetrical radial fins on both sides of the disk) in relation to the rotation direction and with radius $R$ and average viscous friction layer thickness $h$.

\subsection{Suggested algorithm for defining the fluid parameters}

In order to increase the accuracy of paper pulp consistency measurement based on viscosity values it is suggested to measure the viscosity torque at two different sensitive element rotation velocities $\Omega_{1}$ and $\Omega_{2}$. In such case using the formula (3) we obtain the following equations:

$$
\begin{aligned}
& M_{1} \frac{(3+n)}{4 \pi R^{3}}=K\left(\frac{\Omega_{1} R}{h}\right)^{n}, \\
& M_{2} \frac{(3+n)}{4 \pi R^{3}}=K\left(\frac{\Omega_{2} R}{h}\right)^{n} .
\end{aligned}
$$

By dividing separately the left and the right members of equations (4) and (5) we receive and equation

$$
\frac{M_{1}}{M_{2}}=\left(\frac{\Omega_{1}}{\Omega_{2}}\right)^{n}
$$

from which we derive the flow behavior index value

$$
n=\frac{\ln \left(M_{1} / M_{2}\right)}{\ln \left(\Omega_{1} / \Omega_{2}\right)}
$$

and find the flow consistency index $K$

$$
K=M \cdot \frac{(3+n)}{4 \pi R^{3}} \cdot\left(\frac{h}{\Omega R}\right)^{n} .
$$

\subsection{Reduction of impact of friction torque in the sealing of the sensitive element shaft on the measurement results of paper pulp consistency}

Rotational paper pulp consistency meters provide information by measuring the viscous friction torque acting on the sensitive element being rotated with a preset speed in the layer of the paper pulp under investigation. Viscous friction torque influencing the sensitive element is transmitted through the shaft passing the sealing and goes to the torque measurement device. It can be constructed with application of an elastic element, i.e. a torsion spring. The twist angle $\varphi$ of the torsion spring will be proportional to the viscous friction torque $M$ :

$$
\varphi=\frac{M}{\psi},
$$

where is the torsion spring twist coefficient.

With a known torsion spring twist angle $\varphi$ we can define the viscous friction torque and the viscosity coefficient which depends on the paper pulp consistency.

The operation of such paper pulp consistency meter is influenced by the fact that viscous friction torque $M$ on the sensitive element is balanced not only by the twisted torsion $M_{t}$ but also is influenced by the friction torque in bearings and sealing of the sensitive element shaft $M_{S}$. As in the proposed solution the sensitive element rotation frequency is changing regularly it is suggested to measure the torque twisting the torsion spring when the propeller rotation frequency comes close to the working rotation frequency from the lower frequencies $M_{\uparrow_{t}}$ (rotation frequency of the sensitive element increases up to a working value of $\Omega_{1}$ or $\Omega_{2}$ ) and when coming close to the working rotation frequency from the higher frequencies $M_{\downarrow_{t}}$ (rotation frequency of the sensitive element decreases to working value $\Omega_{1}$ or $\Omega_{2}$ ). 
In the dynamic mode the changes of rotation velocity $\varepsilon$ of the sensitive element and its shaft are related to the inertia torque $j$ and the other abovementioned torques by the equation provided below. Increasing the working frequency the rotation accelerates the viscosity torque $M$ and deaccelerates (slows down) the torque of the twisted torsion spring $M_{\uparrow t}$ and torque in sensitive element shaft sealing $M_{S}$ (friction torque is always directed in a way that slows down the movement):

$$
j \cdot \varepsilon=M-M_{\uparrow t}-M_{s} .
$$

Achieving the set value of rotation working frequency $\Omega_{1}$ or $\Omega_{2}$, the rotation velocity of a sensitive element becomes constant and its rotary acceleration $\varepsilon$ equals zero. Formula (10) can be simplified and the relation between the torque created by the torsion spring twisted by angle $\varphi$, viscosity torque and friction torque in sensitive element shaft sealing can be expressed as follows:

$$
M_{\uparrow t}=M-M_{s} \text {. }
$$

If the sensitive element rotation frequency is coming closer to the same working frequency (from the higher frequency area), the sensitive element influenced by the torque twisted at a too high torsion angle is turning to the non-deformed torsion position towards the direction of rotation of the sensitive element. Friction torque in the sensitive element shaft sealing $M_{S}$ together with the viscous friction torque $M$ counteract this rotation:

$$
j \cdot \varepsilon=M-M_{\uparrow t}+M_{s} .
$$

In the stabilized state of the main hollow shaft rotation at the working frequency or the rotary acceleration of the sensitive element $\varepsilon$ equals zero and the equation is as follows:

$$
M_{\downarrow t}=M+M_{s} .
$$

By adding (11) and (13) we can see that friction torques in the shaft sealing of the sensitive element are mutually compensated and the average of measurements of the torque approaching the rotation working frequency of a sensitive element from the high and low ranges are equal to viscosity torque that impact the sensitive element at the rotation working frequency:

$$
M=\frac{M_{\uparrow t}+M_{\downarrow t}}{2}=M_{c e p} .
$$

It is obvious that the friction torque in bearings $M_{\Pi}$ could be taken into account in the abovementioned formulas. Then the formulas (10) - (13) should replace sealing torque friction $M_{S}$ with the sum of shaft sealing torque friction of sensitive element $M_{S}$ and bearings friction torque:

$$
M_{s} \rightarrow M_{s}+M_{\Pi} \text {. }
$$

The final equation (14) doesn't change which means that averaging out the torque values measured by the torsion spring twist approaching the rotation frequency of the main hollow shaft to the set value from the high and low values will enable elimination of impact of friction torque in measurement shaft sealing and bearings.

Paper pulp consistometer is usually placed in the pipe line and in order to ensure laminar flow in the sensitive element rotation area it may be needed to introduce a wider straight section with a consistency meter placed in it. In general the configuration of a pipeline may be complex, with elbows and other elements that will deform the even symmetrical distribution of paper pulp flow speed. Such deformation of flow profile in the pipeline will result in additional torque $M_{V}$ when it interacts with the sensitive element of the consistency meter. This torque will not change its direction when the sensitive element rotation direction changes, but will be added to the viscosity torque at rotation with the set frequency in one direction and will be subtracted when the sensitive element is rotated in the opposite direction. Therefore the measured value of the torque impacting the sensitive element rotated in the same direction as the flow, $M_{+}$will consist of the torque resulting from the viscous friction $M$ and the torque resulting from the speed pressure of the flow $M_{V}$

$$
M_{+}=M+M_{V}
$$

and in the opposite rotation direction $M_{-}$

$$
M_{-}=M-M_{V} \text {. }
$$

Thus, by taking the average value of the measured torques influencing the sensitive element, when rotated in both directions with the same rotation velocity, the torque caused by the speed pressure of the flow due to uneven distribution of the flow speed in the paper pulp flow profile is decreased in the final dependence.

$$
M_{\text {cep }}=\frac{M_{+}+M_{-}}{2}=\frac{M+M_{V}+M-M_{V}}{2}=M .
$$

Thus by rotating the sensitive element in two opposite directions at the same frequency and by further averaging the obtained results it is possible to eliminate the influence of the uneven distribution of paper pulp flow speed in the pipeline on the consistency measurement results.

\subsection{Suggested algorithms for changing the rotation frequency of the sensitive element of the rotational paper pulp consistency meter}

Several ways of changing the rotation frequency of a sensitive element were suggested to measure the paper pulp consistency.

The general feature of the suggested measurement cycles is measurement of the viscous friction torque with gradual approach of the rotation frequency of the sensitive element to the set rotation frequencies. As the frequency increases (approach from below) the torque $M_{\uparrow_{t}}$ is measured. And when the rotation frequency of the sensitive element is decreasing (approach from above) the value of torque $M_{\downarrow t}$ is measured for selected rotation frequency. With this purpose after the measurement is completed and the frequency approaches the rotation frequency $\Omega$ from the lower range, the rotation frequency insignificantly increases and stays permanent for a short time after which it decreases back to and the torque value is measured. The measured torque values are recorded and averaged by applying equation (14). The viscous friction torque values that were measured with changing rotation directions and obtained for two different rotation frequencies are averaged with results obtained for direct sensitive element rotation. And then the paper pulp parameters $K$ and $n$ are defined and subsequent conversion of the viscosity value into the measurement units of paper pulp consistency is done.

The suggested cycles of rotation frequency changes in paper pulp consistency measurement may look like it is shown in Fig. 2. 


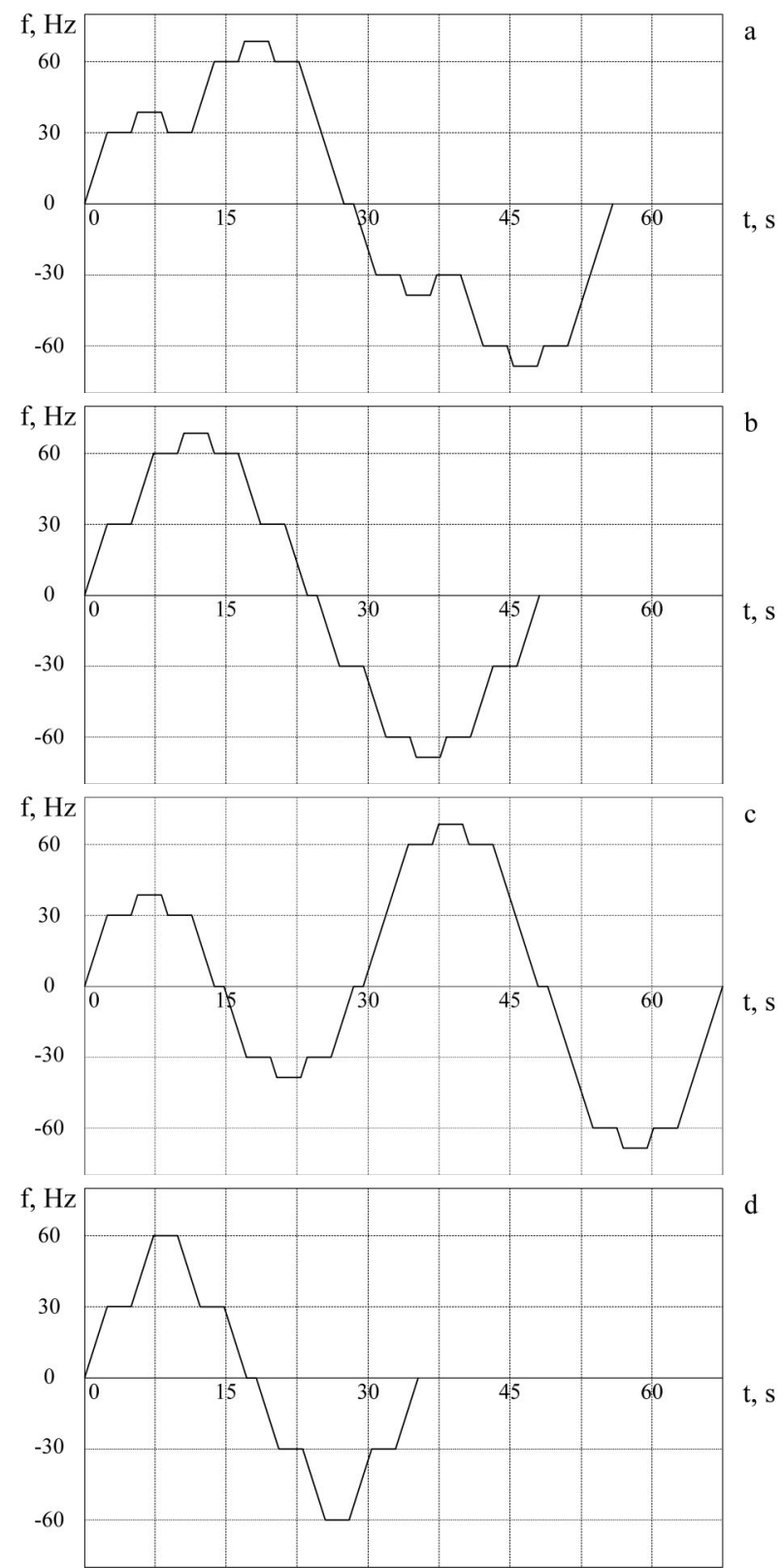

Fig. 2. The suggested cycles of rotation frequency changes in paper pulp consistency meter in time. The ordinate axis shows the voltage frequency powering the motor of the sensitive element mechanism $f(1 / s)$. The motor power voltage frequency with "minus" sign is used to show the opposite direction of sensitive element rotation

Thus, the sequence of voltage frequency changes of the motor power of the sensitive element mechanism can be the following:

a) The measurements are performed during rotation of the sensitive element in one direction at higher and lower frequencies with approaches to the given values from "above" and from "below" after some exceeding of the given value. After that the rotation frequency of the sensitive element passes a zero value and measurements are made using the same algorithm in the opposite direction.

b) The measurements are done in the same way as described in a) but the approach from "above" is not used to measure torque for the lower value.

c) The viscous friction torque is measured for the sensitive element rotating at the lower frequency first both in the direct and opposite directions. Then the same measurements are repeated for higher rotation frequency both in the direct and opposite directions. d) The measurements are performed without exceeding the given rotation frequency values.

By comparing the duration of measurement cycles we can see that the cycle shown in Fig. $2 \mathrm{~d}$ is the shortest. For the curves given above it was assumed that the paper pulp consistency does not change during the measurement cycle and its flow rate is constant.

\section{Presentation and discussion of the research results}

Based on the research results it was shown that by changing the motor rotation frequency for a sensitive element mechanism of a paper pulp consistency meter using a preprogrammed law and by performing measurements for two different frequencies of element rotation it is possible to define the viscosity indexes of the paper pulp $K$ and $n$. These indexes are used to determine the paper pulp effective viscosity $\mu=\frac{\sigma}{\dot{\gamma}}=K(\dot{\gamma})^{n-1}$ which can be converted into consistency value. It is also suggested to average results of viscous friction torque measurement approaching the rotation frequency of a viscometer sensitive element to the working frequency chosen for measurement from the lower and higher frequency ranges. By averaging the results of such measurements the friction torques in sealing and bearings are compensated which enables increasing the accuracy of measurements of paper pulp viscosity and consistency. By averaging the results of measurement with rotation of the sensitive element in different directions it is possible to eliminate the influence of uneven distribution of paper pulp flow speed in the pipeline. Algorithms for changing the rotation frequency of the viscometer sensitive element were suggested to perform measurements in accordance with the method described.

\section{Conclusions}

It is shown in the paper that by using two different rotation frequencies of the sensitive element of a rotational viscometer it is possible to define the flow consistency index and the flow behavior index. Paper pulp viscosity and consistency is defined on the basis of these two indexes. It is also suggested in the paper to average the results of viscous friction torque measurement approaching the rotation frequency of the viscometer sensitive element to the working frequency chosen for measurement from the lower and higher frequency ranges. By averaging the results of such measurement the friction torques in sealing and bearings supporting the sensitive element shaft are compensated. This provides improvement of accuracy of viscosity measurement and the associated paper pulp consistency measurement. By changing the rotation direction of the sensitive element and by further averaging the obtained results it is possible to eliminate the influence of the uneven distribution of paper pulp flow speed in the pipeline.

\section{References}

Blanco, A., Negro, C., Fuente, E., \& Tijero, J. (2007). Rotor Selection for a Searle-Type Device to Study the Rheology of Paper Pulp Suspensions. Chemical Engineering and Processing, 46(1), 37-44. https://doi.org/10.1016/j.cep.2006.04.003

Jakkula, P., \& Tahkola, E. (2000). Microwave Sensor System for the Consistency Measurement in the Pulp and Paper Industry. Sensors 
Update, $\quad 7(1), \quad 211-232 . \quad$ https://doi.org/10.1002/16168984(200001)7:1\%3c211::AID-SEUP211\%3e3.0.CO;2-X

Oy, J.-T., \& Nygård, M. (2010). Metso Rotating Consistency Transmitter. Installation \& Owner's Manual K09157 V1.0 EN Metso Automation Inc. Documentation.

Steffe, J. F. (1996). Rheological Methods in Food process Engineering. 2nd ed. East Lansing, MI, USA: Freeman press. 418 p.

US patent (1973). Torsion digital viscometer: US Patent No 3751975. Appl. No. 171139; filed 12.08.1971; publ. 14.08.1973.
US patent (1997). Rotating consistency transmitter impeller and method: US Patent No. 5684247. Appl. No. 666,903; filed 19.06.1996; publ. 4.11.1997.

US patent (2012). Phase Controller for a Dual Motor Torque Detecting Device: Patent No. US 8171776 B2. Appl. No. 12/523,076; filed 19.12.2007; publ. 8.05.2012.

Waller, M. H. (1993). A tutorial on the measurement of paper stock consistency. ISA Transactions, 32(3), 277-282. https://doi.org/10.1016/0019-0578(93)90026-S

О. М. Романюк, Б. А. Кріль, О. В. Кріль, Г. Б. Крих

Національний університет "Львівська політехніка", м. Львів, Украӥна

\section{РОТАЦІЙНИЙ КОНЦЕНТРАТОМІР ПАПЕРОВОЇ ПУЛЬПИ З ВИМІРЮВАННЯМ}

ДЛЯ ДВОХ ШВИДКОСТЕЙ ЗСУВУ

У сучасних розвинених країнах паперова промисловість посідає третє місце після металургії та хімічної промисловості за обсягами капіталовкладень та за споживанням енергії. Запропоновано спосіб проведення вимірювання концентрації паперової пульпи за допомогою ротаційного віскозиметра, який дає змогу визначити коефіцієнт консистенції рідини $K$ та індекс течії $n$ у степеневому законі Оствальда - де Веле. Спосіб дає змогу усунути вплив моментів сил, які діють на вісь чутливого елемента, а саме моменту сил тертя в ущільненні осі чутливого елемента, моментів сил тертя у підшипниках цієї осі, та моменту сил, який діє на чутливий елемент, і виникає під дією потоку паперової маси в трубопроводі з несиметричним профілем швидкостей течії в околі чутливого елемента концентратоміра на результати вимірювань концентрації паперової маси. Для цього у запропонованому способі проводять вимірювання моменту сили, що діє на чутливий елемент 3 наближенням до вибраних для вимірювання частот обертання чутливого елемента з боку нижчих частот та з боку вищих частот, а також за різних напрямів обертання. Отримані значення моменту сили усереднюють. Вимірювання проводять на двох наперед заданих частотах обертання осі чутливого елемента, та за його обертання у прямому та зворотному напрямках. Частоту обертання чутливого елемента програмовано змінюють за допомогою частотного перетворювача.

Ключові слова: вимірювання концентрації паперової пульпи; ротаційний віскозиметр; неньютонівські рідини; вимірювання в'язкості; коефіцієнт консистенції; індекс течії; ефективна в'язкість.

А. Н. Романюк, Б. А. Криль, А. В. Криль, А. Б. Крых

Национальный университет "Львовская политехника", г. Львов, Украина

\section{РОТАЦИОННЫЙ КОНЦЕНТРАТОМЕР БУМАЖНОЙ ПУЛЬПЫ С ИЗМЕРЕНИЕМ} ПРИ ДВУХ СКОРОСТЯХ СДВИГА

Бумажная промышленность занимает третье место после металлургии и химической промышленности по объемам капитальных вложений и по потреблению энергии. Предложен способ измерения концентрации бумажной пульпы с помощью ротационного концентратомера, позволяющий определить коэффициент консистенции неньютоновской жидкости $K$ и индекс течения $n$ в степенном законе Оствальда - де Веле. Способ позволяет устранить влияние моментов силы, которые действуют на ось чувствительного элемента, а именно момента сил трения в уплотнении оси чувствительного элемента (импеллера), моментов сил трения в подшипниках оси, а также момента сил, действующего на чувствительный элемент, и возникающего под воздействием потока бумажной пульпы в трубопроводе при несимметричном распределении скорости течения в окрестности чувствительного элемента концентратомера на результаты измерений концентрации бумажной массы. С этой целью в предложенном способе измеряют момент силы, действующей на импеллер при приближении к избранной для измерения частоте вращения чувствительного элемента со стороны более низких частот и со стороны более высоких частот и при разных направлениях вращения. Полученные значения момента силы усредняют. Измерения проводят на двух предварительно заданных частотах вращения пропеллера. Частоту вращения пропеллера программировано изменяют с помощью частотного преобразователя.

Ключевые слова: измерение концентрации бумажной массы; ротационный вискозиметр; неньютоновские жидкости; измерение вязкости; коэффициент консистенции; индекс течения; эффективная вязкость. 